\title{
A Study of A Causality Relationship between Profitability and Firm Value: A Comparison between European Countries
}

\author{
Ben Said Hatem \\ Faculty of Law, Economics and Management of Jendouba, University of Jendouba, Jendouba, \\ Tunisia \\ E-mail: hatbensaid@gmail.com
}

Received: April 10, 2016

Accepted: May 7, $2016 \quad$ Published: April 10, 2017

doi:10.5296/ifb.v4i1.9294

URL: http://dx.doi.org/10.5296/ifb.v4i1.9294

\begin{abstract}
The aim of our paper is to test for a causality interdependence between profitability and firm value. To this end, we examined a sample of two European countries: Italy and Poland. Our samples contain 200 firms from each country studied over a period of 4 years from 2007 to 2010. As a measure of firm performance, we use two ratios; return on assets and return on equity. For firm value, we used two ratios; Tobin's Q calculated as long-term debt increased by short-term debt divided by total assets, and Market To Book ratio calculated as market capitalization divided by shareholder's equity. The descriptive statistics show that Italian firms have higher market values. We obtained mean values of 1,123 and 2,0698 of Tobin's Q and MTB, respectively. However, firms in Poland are more profitable than firms in Italy. Using a data panel method, we found that for firms in Italy, there is a causality relationship between profitability, approximated by return on assets and return on equity and firm value, measured by Tobin's Q and Market to book ratio. The effect of profitability on firm value is not significant for specification 3 for Italy. For firms of Poland, a causality relationship is concluded in all specifications.
\end{abstract}

Keywords: Firm value, Firm performance, ROA, ROE, Causality, Tobin’s Q, Market to Book 


\section{Introduction}

Several studies separately focused on the determinants of profitability and firm market value. Thus, our paper examine the causality interdependence between profitabillity and firm value. Jensen \& Meckling (1976) suggest that ownership structure may explain firm performance. Ravenscraft (1983), Schmalensee (1985) argue that growth opportunities and capital intensity can influence firm performance. Tan \& Peng (2003), Peng \& Luo (2000) suggest that firm performance is explained by firm size. Furthermore, many other studies tried to determine how firms can maximize shareholder's wealth. Morck et al. (1988) and McConnell \& Serveas (1990) concluded to a positive and a negative influence of debt on firm value. Agrawal \& Knoeber (1996) find evidence a non significant effect of leverage on firm market value. In our paper, we try to test for a causality relationship between profitability and firm value. To this end, we studied samples from Italy and Poland. The next section will review the main studies that examined the factors explaining profitability and firm value. In Section 3, we present our sample, the tested models and our variables. Section 4 reports the descriptive statistics and our empirical results. A sensitivity analysis of our results by sectors is made in section 5 . The last section concludes our main results.

\section{The Literature Review}

Similar to Falk \& Gordon (1977) and Falk \& Miller (1977), Keith \& Mark (1994) examined the presence of a causality relationship between performance and firm value. The authors use simultaneous equations models to describe interdependence between the three variables: Goodwill, profitability and firm value. Profitability is approximated by annual net income. Firm value is measured by shares market value. Examining a sample of 2693 firms over a period of 3 years from 1989 to 1991, the authors found mean values of Goodwill, profitability and firm value of 101.07, 87.08 and 1624.72, respectively. Using the OLS estimation method, they found a significant causality association between performance and firm value.

Similarly the work of Wei \& Varela's (2003), Boycko et al. (1996), Shleifer (1998), Chen et al. (2000) and Wang (2005), Alex, Ayse, \& Eason (2009) studied the factors explaining firm value by testing the role of ownership structure. The authors measure firm value using Tobin's Q that is calculated as shares market value increased of total liabilities divided by total assets. Investigating a sample of 4315 firms over a period of 8 years from 1996 to 2003, the authors concluded to a nonlinear relationship between ownership structure and firm value. Likewise, the authors also concluded that ownership concentration significantly affects firm value. The results point, also, to a positive and a statistically significant effect of firm performance, measured by return on assets, ROA, on firm value. However, for the entire period, firms with lower debt have higher market values.

Following works of Slack (1991). Neely (1994), Zhu (2000), Hillman \& Keim (2001), Kirby (2005), Richard et al. (2009), Marius, Delia, \& Cecilia (2014) examine the determinants of the performance of Romanian companies. The authors measure firm performance using return on assets, ROA, and return on equity, ROE, ratios. Examining a sample of 55 firms for a period of 14 years from 1999 to 2012, they found mean values of ROA and ROE of 293.8876 and 292.2963 respectively. The average sample size is 378.5 , while each firm 
employs on average of 305.2143 employees. These results point to a positive and a statistically significant effect of these variables, number of employees, firm size and capital intensity.

\section{Data and Methodology}

\subsection{Sample Selection}

To test the causality association between profitability and firm value, we examined samples of 200 firms in Italy and 200 firms in Poland over a period of 4 years from 2007 to 2010. The data are extracted from Amadeus database.

\subsection{Choice of Variables and Hypothesis}

The dependent variables:

Dependent variables:

Firm value: like Sun et al. (2002), Wei \& Varela (2003) and Wei et al. (2005), we use, alternatively, two measures of firm value:

-Tobin's Q: approximated as the ratio of market capitalization increased of short-term and long-term debt divided by total assets.

-Market To Book ratio: approximated as market capitalization divided by shareholders' equity.

A higher value of shareholder wealth means a value of growth opportunities and a high amount of profitability. Indeed, shareholders are willing to spend more money to acquire shares of firms with higher profitability. Hypothesis 1: there is a positive effect between shareholder wealth and firm performance.

Similarly, we use alternatively two measures of firm performance:

-Return on assets (ROA): approximated as the ratio of net income divided by total assets (Goodman \& Bamford, 1989; Hanna, 2011).

-Return on equity (ROE): approximated as the ratio of net income divided by shareholders' equity.

High performance can increase dividends, which would enhance share price. Hypothesis 2a: firm performance positively affect shareholder wealth. However, high profitability means more cash in the hands of shareholders. Excess liquidity may create agency problems between owners and insiders. We expect, in our case, a reduction in shareholder wealth. Hypothesis $\boldsymbol{2} \boldsymbol{b}$ : firm performance negatively affects shareholder wealth.

The independent variables:

Leverage: Randoy \& Goel (2003) measure debt ratio as long term debt divided by total assets. In or paper, we measure debt ratio as the sum of long term debt and short-term debt divided by total assets. Alex (2009) argues that high debt leads to more financial expenses, which will 
reduce profitability. This negative relationship is predicted by trade off theory (Fama \& French, 2002; Myers, 1993; Shyam-Sunder \& Myers, 1999). Hypothesis 3 a: leverage negatively explains firm performance. However, according to Kouki \& Ben Said (2012), a high debt decreases agency problems between shareholders and managers, which will positively explain shareholder wealth. Hypothesis $3 \boldsymbol{b}$ : leverage positively affects firm value.

Firm size: according to Gracia-Teruel \& Martinez-Solano’s (2007), we approximate firm size as the logarithm of total assets. Kouki \& Ben Said (2012) and Alex (2009) argue that larger firms are exposed to agency problems between managers and investors, which will negatively explain firm performance. Similarly, the largest firms finance their activity by share issuance. Financing cost of share issuance is higher than that of debt. Then, we expect a negative influence of firm size on firm performance. Hypothesis 4a: firm size negatively explains firm performance. A large firm size means more transparency and more information available to external investors. A large firm size sends a good signal to shareholders on their financial health. Hypothesis $\mathbf{4 b}$ : firm size positively explains shareholder wealth.

Age: like Shane (1998) and Jeremy \& Peter (2008), we measure the impact of firm age. Indeed, the older the firm is, the more it is well reputed, the more it can get funding with lower cost. Hypothesis 5a: there is a positive relation between firm age and performance. Similarly, shareholders are still interested in buying shares of older firms to maximize their earnings. Hypothesis $\mathbf{5 b}$ : there is a positive relationship between age and shareholder wealth.

Table 1. Variables and expected signs

\begin{tabular}{|l|l|l|l|}
\hline Variables & Abbreviation & Formulation & Expected sign \\
\hline Tobins' Q & Tobin Q & (MVE+STD+LTD)/TA & $\begin{array}{l}\text { Dependant } \\
\text { variable }\end{array}$ \\
\hline Market to Book & MTB & MVE/Shareholder's equity & $\begin{array}{l}\text { Dependant } \\
\text { variable }\end{array}$ \\
\hline $\begin{array}{l}\text { Firm } \\
\text { performance }\end{array}$ & ROA & Net income/TA & $\begin{array}{l}\text { Dependant } \\
\text { variable }\end{array}$ \\
\hline Firm & ROEformance & Net income / Shareholder's equity & $\begin{array}{l}\text { Dependant } \\
\text { variable }\end{array}$ \\
\hline Leverage & DR & (LTD+STD)/TA & -/+ \\
\hline Firm size & SIZE & Ln (TA) & -/+ \\
\hline Firm age & AGE & $\begin{array}{l}\text { Number of years between incorporated year and } \\
\text { outstanding year. }\end{array}$ & + \\
\hline TA: total assets. LTD: Long term debt. STD: Short term debt. MVE: Market value equity &
\end{tabular}

\subsection{The Models}

To test for the presence of a causal relationship between performance and firm value, we use the following models (Ng, Yuce, \& Chen, 2009). 


$$
\begin{aligned}
& \text { TOBIN'S } Q_{i t}=\alpha_{0}+\alpha_{1} * R O A+\alpha_{2} * D R+\alpha_{3} * S_{Z} I E_{i t}+\alpha_{4} * A G E_{i t}+\varepsilon_{i t} \\
& M T B_{i t}=\alpha_{0}+\alpha_{1} * R O A+\alpha_{2} * D R_{i t}+\alpha_{3} * S I Z E_{i t}+\alpha_{4} * A G E_{i t}+\varepsilon_{i t} \\
& \text { TOBIN'S } Q_{i t}=\alpha_{0}+\alpha_{1} * R O E_{i t}+\alpha_{2} * D R+\alpha_{3} * S_{Z} E_{i t}+\alpha_{4} * A G E_{i t}+\varepsilon_{i t} \\
& M T B_{i t}=\alpha_{0}+\alpha_{1} * R O E_{i t}+\alpha_{2} * D R_{i t}+\alpha_{3} * \operatorname{SIZE}_{i t}+\alpha_{4} * A G E_{i t}+\varepsilon_{i t} \\
& R O A_{i t}=\alpha_{0}+\alpha_{1} * \text { TOBIN'S } Q_{i t}+\alpha_{2} * D R_{i t}+\alpha_{3} * S_{Z I Z} E_{i t}+\alpha_{4} * A G E_{i t}+\varepsilon_{i t} \\
& R O A_{i t}=\alpha_{0}+\alpha_{1} * M T B_{i t}+\alpha_{2} * D R_{i t}+\alpha_{3} * \operatorname{SIZE}_{i t}+\alpha_{4} * A G E_{i t}+\varepsilon_{i t} \\
& R O E_{i t}=\alpha_{0}+\alpha_{1} * \text { TOBIN'S } Q_{i t}+\alpha_{2} * D R_{i t}+\alpha_{3} * S_{Z I Z} E_{i t}+\alpha_{4} * A G E_{i t}+\varepsilon_{i t} \\
& R O E_{i t}=\alpha_{0}+\alpha_{1} * M T B_{i t}+\alpha_{2} * D R_{i t}+\alpha_{3} * \operatorname{SIZE}_{i t}+\alpha_{4} * A G E_{i t}+\varepsilon_{i t}
\end{aligned}
$$

\section{The Empirical Results}

\subsection{The Descriptive Statistics}

Distribution of our sample across the five sectors is presented in table 2. The sample of Italy contains 200 firm distributed as follows: 38 companies operating in the service sector, 17 firms in the real estate sector, 65 companies in the intellectual and professional sector, 3 firms in agriculture and mining and 77 firms in manufacturing. The sample of Poland consists of 170 firms distributed as follow: 62 firms in the Service sector, 33 firms in the real estate sector, 36 firms in the intellectual and professional sector, 4 firms in agriculture and mining and 65 firms in manufacturing. For both countries, most firms operate in the manufacturing sector. However, our samples contain a small number of firms in agriculture and mining.

Table 2. Distribution of our sample into activity sectors

\begin{tabular}{|l|l|l|l|l|l|l|}
\hline & Service & $\begin{array}{l}\text { Real estate's } \\
\text { activities }\end{array}$ & $\begin{array}{l}\text { Professionals } \\
\text { activities }\end{array}$ & $\begin{array}{l}\text { Mining and } \\
\text { agriculture }\end{array}$ & Manufacturing & Total \\
\hline Italy & 38 & 17 & 65 & 3 & 77 & 200 firms \\
\hline Poland & 62 & 33 & 36 & 4 & 65 & 200 firms \\
\hline
\end{tabular}

Table 3 show that shareholder wealth of Poland is higher than that of Italy. Tobin's Q and MTB mean values are respectively, 1,296 and 2,159. Similarly, firms of Poland are more profitable than firms of Italy. Mean values of profitability are 0.0392 for return on assets and 0.0921 for return on equity. This high level of profitability for firms of Poland is explained by the lowest debt ratio of 0.434 . However, firms of Italy have an average debt ratio of 0.544 . Similarly, the descriptive statistics show that firms of Italy are older with an average age of 30.818 years. Firm size in the two countries is equal. It is 19.969 for Italy and 18.701 for Poland. 


\section{Macrothink}

Table 3. Descriptive statistics

\begin{tabular}{|c|c|c|c|c|c|}
\hline & \multicolumn{4}{|l|}{ Italy } & \\
\hline & OBS & MEAN & STD DEV & MIN & MAX \\
\hline Tobin's Q & 710 & 1,123 & 0,642 & 0,279 & 6,814 \\
\hline Leverage & 744 & 0,544 & 0,176 & 0,0381 & 0,996 \\
\hline ROA & 751 & 0,00642 & 0,0991 & $-0,924$ & 0,378 \\
\hline ROE & 712 & 0,0363 & 0,208 & $-0,908$ & 0,932 \\
\hline MTB & 696 & 2,0698 & 6,253 & 0 & $120,86.5$ \\
\hline SIZE & 751 & 19,969 & 1,760 & 16,475 & 25,847 \\
\hline \multirow[t]{3}{*}{ AGE } & 794 & 30,818 & 27,913 & 1 & 146 \\
\hline & \multicolumn{4}{|c|}{ Poland } & \\
\hline & OBS & MEAN & STD DEV & MIN & MAX \\
\hline Tobin's Q & 637 & 1,296 & 0,868 & 0,337 & 10,224 \\
\hline Leverage & 719 & 0,434 & 0,172 & 0,000237 & 0,892 \\
\hline ROA & 724 & 0,0392 & 0,0903 & $-0,709$ & 0,413 \\
\hline ROE & 718 & 0,0921 & 0,173 & $-0,786$ & 0,919 \\
\hline MTB & 635 & 2,159 & 7,948 & 0,00688 & 191,578 \\
\hline SIZE & 724 & 18,701 & 1,472 & 12,0832 & 23,350 \\
\hline AGE & 798 & 30,796 & 29,277 & 1 & 200 \\
\hline
\end{tabular}

\subsection{The Causality Relationship between Profitability and Firm Value}

The results on the causality interdependence between performance and firm value are shown in Table 4. Firm value is measured, alternately, by Tobin's Q and MTB ratio. Firm performance is measured by two ratios. 


\section{Mll Macrothink}

Table 4. Causality relationship between profitability and firm value

\begin{tabular}{|c|c|c|c|c|c|c|c|c|}
\hline & \multicolumn{8}{|l|}{ Italy } \\
\hline & Spef 1 & Spef 2 & Spef 3 & Spef 4 & Spef 5 & Spef 6 & Spef 7 & Spef 8 \\
\hline & $\mathbf{Q}$ & $\mathbf{Q}$ & MTB & MTB & ROA & ROA & ROE & ROE \\
\hline $\mathrm{C}$ & $1,941^{* * *}$ & $2,0606^{* * * *}$ & $8,00864^{*}$ & $3,168^{* * * *}$ & $-0,0880^{* * *}$ & $-0,0113$ & $-0,377^{* * *}$ & $-0,322^{* * *}$ \\
\hline Tobin’s Q & & & & & $0,0339^{* * *}$ & & $0,0683^{* * *}$ & \\
\hline MTB & & & & & & $0,00165^{* * * *}$ & & $0,0376^{* * *}$ \\
\hline ROA & $1,893^{* * *}$ & & 0,593 & & & & & \\
\hline ROE & & $0,578^{* * *}$ & & $2,0534^{* * *}$ & & & & \\
\hline DR & $0,441^{* * * *}$ & $0,338^{* * * *}$ & $6,584^{* * *}$ & $1,348^{* * *}$ & $-0,132^{* * *}$ & $-0,147^{* * *}$ & $-0,125^{* * *}$ & $-0,151^{* * * *}$ \\
\hline SIZE & $-0,0531^{* * *}$ & $-0,0560^{* * *}$ & $-0,436^{*}$ & $-0,116^{* * *}$ & $0,00718^{* * *}$ & $0,00559^{* * *}$ & $0,0213^{* * *}$ & $0,0202^{* * *}$ \\
\hline Age & $-0,00315^{* * *}$ & $-0,00314^{* * *}$ & $-0,0151$ & $-0,00726^{* * * *}$ & $-0,0000481$ & $-0,000160^{* * *}$ & $-0,000176^{*}$ & $-0,000106$ \\
\hline OBS & 693 & 653 & 684 & 651 & 693 & 684 & 653 & 651 \\
\hline $\begin{array}{l}\text { R squared } \\
\text { (\%) } \\
\text { Wald chi2 }\end{array}$ & 643,66 & 430,62 & 15,04 & 677,50 & 476,43 & 306,24 & 248,15 & 281,52 \\
\hline \multirow[t]{4}{*}{ Prob> F } & 0 & 0 & 0,0046 & 0 & 0 & 0 & 0 & 0 \\
\hline & Poland & & & & & & & \\
\hline & Spef 1 & Spef 2 & Spef 3 & Spef 4 & Spef 5 & Spef 6 & Spef 7 & Spef 8 \\
\hline & $\mathbf{Q}$ & $\mathbf{Q}$ & MTB & MTB & ROA & ROA & ROE & ROE \\
\hline $\mathrm{C}$ & $1,831^{\text {*** }}$ & $2,102^{* * *}$ & $1,373^{* * *}$ & $0,996^{* * *}$ & $-0,0272^{* *}$ & 0,0150 & $-0,197^{* * *}$ & $-0,138^{* * *}$ \\
\hline Tobin’s Q & & & & & $0,0390^{* * * *}$ & & $0,0771^{* * * *}$ & \\
\hline MTB & & & & & & $0,00951^{\text {**** }}$ & & $0,0419^{* * *}$ \\
\hline ROA & $4,149^{* * *}$ & & $6,672^{* * *}$ & & & & & \\
\hline ROE & & $1,997^{* * *}$ & & $4,363^{* * *}$ & & & & \\
\hline DR & $0,453^{* * * *}$ & 0,0717 & $1,250^{* * *}$ & $0,830^{* * *}$ & $-0,0940^{* * *}$ & $-0,126^{* * *}$ & $-0,0333^{* * *}$ & $-0,0456^{* * *}$ \\
\hline SIZE & $-0,0483^{* * *}$ & $-0,0542^{* * *}$ & $-0,0229$ & $-0,0296$ & $0,00303^{* * * *}$ & $0,00300^{* * * *}$ & $0,00967^{* * *}$ & $0,00845^{* * *}$ \\
\hline Age & $-0,00200^{* * * *}$ & $-0,00153^{* * *}$ & $-0,00416^{* * * *}$ & $-0,00297^{* * *}$ & $0,000139^{* * * *}$ & $0,000188^{* * * * *}$ & $0,000505^{* * *}$ & $0,000372^{* * *}$ \\
\hline OBS & 616 & 612 & 616 & 612 & 634 & 634 & 630 & 630 \\
\hline $\begin{array}{l}\text { Rsquared(\%) } \\
\text { Waldchi2 }\end{array}$ & 499,72 & 412,19 & 185,97 & 288,73 & 770,72 & 2430,02 & 16308,86 & 1014,25 \\
\hline Prob $>$ F & 0 & 0 & 0 & 0 & 0 & 0 & 0 & 0 \\
\hline
\end{tabular}

Note. ${ }^{* * *},{ }^{* * *}$ : significance at $10 \%, 5 \%$ and $1 \%$ levels respectively.

Firm value: shareholder wealth measured by Tobin's $Q$ and MTB ratios positively affects firm performance in Italy and Poland (first hypothesis). This result means that more growth opportunities improve firm profitability.

Firm performance: the results of firm performance confirm our hypothesis 2a. Indeed, an increase in financial returns leads to an improvement in shareholder wealth. This result is not valid for specification 3 for Italy.

Leverage: the results show that debt negatively affects financial profitability of firms in Italy and Poland (Baker \& Wurgler, 2002; Rajan \& Zingales, 1995; Titman \& Wessels, 1988). Indeed, an increase in debt leads to more financial expenses, and consequently a reduction in cash holdings (hypothesis 3a). However, the hypothesis (3b) on the impact of debt on shareholder wealth, is valid for Italy and Poland. This result means that debt reduces agency problems within firms in Italy, which will favourably affect shareholdler wealth. In fact, managers of these firms behave to maximise shareholder wealth. The effect of debt on shareholder wealth is not statistically significant in specification 2 for Poland. 
Size: the results of firm size seem to reject our hypothesis (4a). Indeed, size positively affects firm performance in Italy and Poland (Marius, Delia, \& Cecilia, 2014). This means that managers of the largest firms are stimulated to work more to maximize shareholder wealth. This may imply that managers of the largest firms are paid more. Furthermore, it seems that size negatively affects shareholder wealth for both countries except specifications 3 and 4 for Poland. This result means that a large size leads to more agency problems between managers and owners, which will send a bad signal to outside investors.

Age: older firms have lower market values. This finding does not confirms our hypothesis $5 \mathrm{~b}$. In fact, an increase in age makes it difficult for outsiders to buy a number of shares from these firms. Likewise, age positively affects the financial viability of firms from Poland. This result confirms our hypothesis 5 a. We found a negative effect for Italy except specification 5 and 8.

\section{The Causality Relationship between Profitability and Firm Value and the Effect of Activity Sectors}

Like Zainudin (2008), we study the impact of activity sectors on causality between profitability and firm value. We maintain as firm performance measure, return on assets, ROA, and firm value measure, Tobin's $Q$ ratio. The results are reported for the five sectors; the service sector, the real estate sector, intellectual and professional activities, agriculture and mining and the manufacturing sector. The results point to a causal relationship for four sectors in Poland and all activity sectors for Italy. Furthermore, this causal relationship is not valid for the agriculture and mining sector in Poland. The effect of profitability on corporate value is non negative and statistically significant except for the agriculture and mining sector for firms in Poland. Leverage positively affects shareholder wealth for the real estate, intellectual and professional industries and agriculture and mining sectors in Italy. This positive effect is found for specifications 5 and 9 for Poland. However, we found a negative effect of leverage on firm value for the real estate sector in Poland. The influence of firm size on performance become negatively and statistically significant for the service and real estate sectors in Poland. A contradictory result is found for other activities in Italy and Poland. The effect of firm size on firm value is negative and statistically significant for all specifications except for the agriculture and mining sector in Italy, and the real estate, professional and agriculture and mining sectors in Poland. Older firms operating in the professional sector in Poland have higher profitability. A contradictory result is found for the professional sector in Italy, and the agriculture and mining sector in Poland. Older firms have lower market values in Italy and the professional sector in Poland. 
Table 5. Role of activity sectors in explaining the causality relationship between profitability and firm value

\begin{tabular}{|c|c|c|c|c|c|c|c|c|c|c|}
\hline & \multicolumn{10}{|c|}{ Italy } \\
\hline & \multicolumn{2}{|c|}{ Service } & \multicolumn{2}{|c|}{ Real estate } & \multicolumn{2}{|c|}{ Profess } & \multicolumn{2}{|c|}{ agrimin } & \multicolumn{2}{|c|}{ manuf } \\
\hline & Spef 1 & Spef 2 & Spef 3 & Spef 4 & Spef 5 & Spef 6 & Spef 7 & Spef 8 & Spef 9 & Spef 10 \\
\hline & $\mathbf{Q}$ & ROA & $\mathbf{Q}$ & ROA & $\mathbf{Q}$ & ROA & Q & ROA & Q & ROA \\
\hline $\mathrm{C}$ & $3,276^{* * *}$ & $-0,142^{* * * *}$ & $1,762^{* * *}$ & $-0,244^{* *}$ & $1,838^{* * *}$ & $-0,136^{* * *}$ & 0,185 & $-0,0190$ & $2,0741^{* * *}$ & $-0,151^{* * *}$ \\
\hline Tobin's Q & & $0,0193^{* * *}$ & & $0,0851^{* * *}$ & & $0,0690^{* * *}$ & & $0,0907^{* * *}$ & & $0,0365^{* * *}$ \\
\hline ROA & $1,0653^{* * *}$ & & $2,288^{* * *}$ & & $2,653^{* * *}$ & & $5,536^{* * *}$ & & $2,0461^{* * *}$ & \\
\hline $\mathrm{DR}$ & 0,0758 & $-0,0920^{* * *}$ & $0,899^{* * *}$ & $-0,178^{* * * *}$ & $0,825^{* * *}$ & $-0,126^{* * *}$ & $1,660^{* *}$ & $-0,363$ & 0,0956 & $-0,172^{* * *}$ \\
\hline SIZE & $-0,106^{* * *}$ & $0,00945^{* * *}$ & $-0,0650^{* * *}$ & $0,0136^{* * *}$ & $-0,0608^{* * *}$ & $0,00736^{* * *}$ & $-0,00466$ & $0,00503^{*}$ & $-0,0492^{* * *}$ & $0,0116^{* * *}$ \\
\hline Age & $-0,00418^{* * *}$ & 0,0000341 & $-0,00140^{* * *}$ & $-0,0000282$ & $-0,000802^{* *}$ & $-0,000157^{* * *}$ & $-0,00430^{* *}$ & 0,000764 & $-0,00328^{* * *}$ & $-0,0000675$ \\
\hline OBS & 128 & 130 & 56 & 56 & 227 & 227 & 11 & $\mathbb{1 1}$ & 275 & 275 \\
\hline $\begin{array}{l}\text { Rsquared } \\
\text { (\%)Waldchi2 }\end{array}$ & 37,79 & 166,81 & 60,11 & 35,55 & 211,94 & 170,21 & 264,86 & 63,96 & 114,48 & 226,16 \\
\hline \multirow[t]{5}{*}{ Prob> F } & 0 & 0 & 0 & 0 & 0 & 0 & 0 & 0 & 0 & 0 \\
\hline & \multicolumn{10}{|c|}{ Polanda } \\
\hline & \multicolumn{2}{|c|}{ Service } & \multicolumn{2}{|c|}{ Real estate } & \multicolumn{2}{|c|}{ Profess } & \multicolumn{2}{|c|}{ agrimin } & \multicolumn{2}{|c|}{ manuf } \\
\hline & Spef 1 & Spef 2 & Spef 3 & Spef 4 & Spef 5 & Spef 6 & Spef 7 & Spef 8 & Spef 9 & Spef 10 \\
\hline & $\mathbf{Q}$ & ROA & $\mathbf{Q}$ & ROA & $\mathbf{Q}$ & ROA & $\mathbf{Q}$ & ROA & $\mathbf{Q}$ & ROA \\
\hline $\mathrm{C}$ & $2,570^{* * *}$ & $0,102^{* * *}$ & $-0,165$ & $0,232^{* * *}$ & $0,995^{* *}$ & $-0,144^{* * *}$ & 75,131 & $-6,738^{* * *}$ & $-1,444^{* * *}$ & $-1,617^{* * *}$ \\
\hline Tobin' s Q & & $0,0306^{* * *}$ & & $0,0144^{* * *}$ & & $0,0338^{* * *}$ & & 0,0416 & & $0,0423^{* * *}$ \\
\hline ROA & $3,692^{* * *}$ & & $4,744^{* * *}$ & & $2,587^{* * *}$ & & 9,915 & & $3,435^{* * *}$ & \\
\hline DR & $-0,279$ & $-0,0992^{* * *}$ & $-1,212^{*}$ & $-0,0397$ & $1,0964^{* * *}$ & 0,00461 & 22,628 & $-1,968^{*}$ & $0,378^{* *}$ & $-0,345^{* * *}$ \\
\hline SIZE & $-0,0720^{*}$ & $-0,00313^{*}$ & 0,0972 & $-0,00944^{* *}$ & $-0,0125$ & $0,00726^{* * *}$ & $-5,149$ & $0,460^{* *}$ & $-0,0338^{* *}$ & $0,105^{* * *}$ \\
\hline Age & 0,000703 & $-0,000158$ & 0,00165 & 0,000100 & $-0,00293^{* * *}$ & $0,000286^{* * *}$ & 0,708 & $-0,0611^{* *}$ & $-0,000963$ & $-0,00534$ \\
\hline OBS & 175 & 185 & 106 & 106 & 105 & 108 & 7 & 7 & 224 & 226 \\
\hline $\begin{array}{lr}\text { R squared } \\
\text { (\%)Waldchi2 } \\
\end{array}$ & 59,50 & 274,47 & 12,55 & 34,62 & 52,54 & 92,56 & $-31,67$ & 84,50 & 103,44 & 26,41 \\
\hline Prob> F & 0 & 0 & 0,0137 & 0 & 0,0 & 0 & 0,6852 & 0,1006 & 0 & 0 \\
\hline
\end{tabular}

Note. ${ }^{* * *},{ }^{* * *}$ : significance at $10 \%, 5 \%$ and $1 \%$ levels respectively.

\section{Conclusion}

Several works have identified the factors explaining firm profitability and firm value (Harvey et al., 2004). The aim of our paper is to identify for the presence of a causality association between profitability and firm value. The descriptive statistics show that Italian firms have higher market values. A mean values of 1,123 and 2,0698 of Tobïn's Q and MTB, respectively. However, firms in Poland are more profitable than firms in Italy. Using a data panel method, we concluded to a causality relationship between profitability and firm value. However, the causality relationship between return on assets and our dependant variable is not statistically significant for firms in Italy. For firms in Poland a causality relationship is detected in all specifications. For our control variables, the results are as follows: a higher debt ratio leads to higher market value, except specification 2 for Poland. Firms can maximize their shareholder wealth by maximising their debt ratio. The effect of debt ratio on firm performance is negative and statistically significant for all countries. The largest firms of Italy and Poland are more profitable. The effect of firm size on firm value is negative and statistically significant for Italy (all specifications) and Poland ( specification 1 and 2). 
Finally, it seems that firm age negatively and significantly affects firm value and profitability of firms in Italy. However, we found a negative effect of firm age on shareholder's wealth, and a positive effect on firm performance in Poland. As for the effect of activity sector, we concluded that a causality relationship is not checked for the agriculture and mining for firms in Poland.

\section{References}

Agrawal, A., \& Knoeber, C. R. (1996). Firm performance and mechanismis to control agency problems between managers and shareholders. Journal of Financial and Quantitative Analysis, 31, 377-397. https://doi.org/10.2307/2331397

Baker, M., \& Wurgler, J. (2002). Market timing and capital structure. Journal of Finance, 57, 1-30. https://doi.org/10.1111/1540-6261.00414

Boycko, M., Shleifer, A., \& Vishny, R. (1996). A theory of privatization. Economic Journal, 106, 309-319. https://doi.org/10.2307/2235248

Chauvin, K. W., \& Hirschey, M. (1994). Goodwill, Profitability, and the Market Value of the Firm. Journal of Accounting and Public Policy, 13, 159-180. https://doi.org/10.1016/0278-4254(94)90018-3

Chen, G., Firth, M., \& Kim, J. B. (2000). The post-issue market performance of initial public offerings in China's new stock markets. Review of Quantitative Finance and Accounting, 14(4), 319-339. https://doi.org/10.1023/A:1008358609204

Falk, H., \& Gordon, L. A. (1977). Imperfect markets and the nature of goodwill. Journal of Business, Finance and Accounting, 44(4), 443-463. https://doi.org/10.1111/j.1468-5957.1977.tb00727.x

Falk, H., \& Miller, J. C. (1977). Amortization of advertising expenditures. Journal of Accounting Research, 15(1), 12-22. https://doi.org/10.2307/2490553

Fama, E. F., \& French, K. R. (2002). Testing trade-off and pecking order predictions about dividends and debt. Review of Financial Studies, 15, 1-13. https://doi.org/10.1093/rfs/15.1.1

Galbreath, J., \& Galvin, P. (2008). Firm factors, industry structure and performance variation: New empirical evidence to a classic debate. Journal of Business Research, 61, 109-117. https://doi.org/10.1016/j.jbusres.2007.06.009

Garcia-Teruel, P. J., \& Martinez-Solano, P. (2007). Effects of working capital on SME profitability. International Journal of Managerial Finance, 3(2), 164-177. https://doi.org/10.1108/17439130710738718

Goodman, E. J., \& Bamford, J. (1989). Small firms and industrial districts in Italy. New York: Routledge.

Hanna, W. (2011). The impact of management and board ownership on profitability in banks with different strategies. Journal of Banking \& Finance, 35, 3300-3318. https://doi.org/10.1016/j.jbankfin.2011.05.013 
Harvey, C. R., Lins, K. V., \& Roper, A. H. (2004). The effect of capital structure when expected agency costs are extreme. Journal of Financial Economics, 74, 3-30. https://doi.org/10.1016/j.jfineco.2003.07.003

Hillman, A. J., \& Keim, G. D. (2001). Shareholder value, stakeholder maniagement and social issues: What's the bottom line?. Strategic Management Journal, 22(2), 125-139. https://doi.org/10.1002/1097-0266(200101)22:2<125::AID-SMJ150>3.0.CO;2-H

Jensen, M. C., \& Meckling, W. H. (1976). Theory of the firm: managerial behavior, agency costs and ownership structure. Journal of Financial Economics, 3(4), 305-360. https://doi.org/10.1016/0304-405X(76)90026-X

Kirby, J. (2005). Toward a theory of high performance. Harvard Business Review, 83, 30-39.

Marius, D., \& Cecilia (2014). Economic determinants of Romanian firms' financial performance. Procedia-Social and Behavioral Sciences, 124, 272-281. https://doi.org/10.1016/j.sbspro.2014.02.486

McConnell, J. J., \& Serveas, H. (1990). Additional evidence on equity ownership and corporate value. Journal of Financial Economics, 27, 595-612. https://doi.org/10.1016/0304-405X(90)90069-C

Mondher, K., \& Hatem, B. S. (2012). Capital Structure Determinants: New Evidence from French Panel Data. International Journal of Business and Management, 7(1). http://dx.doi.org/10.5539/ijbm.v7n1p214

Morck, R., Shleifer, A., \& Vishny, R. (1988). Management ownership and market valuation: An empirical analysis. Journal of Financial Economics, 20, 293-316. https://doi.org/10.1016/0304-405X(88)90048-7

Myers, S. C. (1993). Still searching for optimal capital structure. Journal of Applied Corporate Finance, 6, 4-14. https://doi.org/10.1111/j.1745-6622.1993.tb00369.x

Neely, A. D. (1994). Performance measurement system design-third phase, draft of the fourth section of the Performance Measurement System Design Workbook.

Ng, A., Yuce, A., \& Chen, E. (2009). Determinants of state equity ownership, and its effect on value/performance: China's privatized firms. Pacific-Basin Finance Journal, 17, 413-443. https://doi.org/10.1016/j.pacfin.2008.10.003

Peng, M. W., \& Luo, Y. (2000). Managerial ties and firm performance in a transition economy: the nature of a micro-macro link. Academy of Management Journal, 43(3), 486-501. https://doi.org/10.2307/1556406

Rajan, R. G., \& Zingales, L. (1995). What do we know about capital structure? Some evidence from international data. Journal of Finance, 50, 1421-1460. https://doi.org/10.1111/j.1540-6261.1995.tb05184.x

Randoy, T., \& Goel, S. (2003). Ownership structure, founder leadership, and performance in Norwegian SMES: Implications for financing entrepreneurial opportunities. Journal of 
Business Venturing, 18(5), 619-637. https://doi.org/10.1016/S0883-9026(03)00013-2

Ravenscraft, D. J. (1983). Structure-profit relationships at the line of business and industry level. Review of Economics and Statistics, 65, 22-3 1. https://doi.org/10.2307/1924405

Richard, P. J., Devinney, T. M., Yip, G. S., \& Johnosn, G. (2009). Measuring organizational performance: Towards methodological best practice. Strategic Management Journal, 1-44. https://doi.org/10.1177/0149206308330560

Schmalensee, R. (1985). Do markets differ much?. American Economic Review, 75, 341-351.

Shane, S. A. (1998). Making new franchise systems work. Strategic Management Journal, 19, 697-707.

https://doi.org/10.1002/(SICI)1097-0266(199807)19:7<697::AID-SMJ972>3.0.CO;2-O

Shleifer, A., (1998). State versus private ownership. Journal of Economic Perspectives, 12, 133-150. https://doi.org/10.1257/jep.12.4.133

Shyam-Sunder, L., \& Myers, S. C. (1999). Testing static tradeoff against pecking order models of capital structure. Journal of Financial Economics, 51, 219-244. https://doi.org/10.1016/S0304-405X(98)00051-8

Slack, N. (1991). The Manufacturing Advantage: Achieving Competitive Manufacturing Operations. London: Mercury.

Sun, Q., Tong, W. H. S., \& Tong, J. (2002). How does government ownership affect firm performance? Evidence from China's privatization experience. Journal of Business Finance and Accounting, 29(1\& 2), 1-27. https://doi.org/10.1111/1468-5957.00422

Tan, J., \& Peng, M. W. (2003). Organizational slack and firm performance during economic transitions: two studies from an emerging economy. Strategic Management Journal, 24, 1249-1263. https://doi.org/10.1002/smj.351

Titman, S., \& Wessels, R. (1988). The determinants of capital structure choice. Journal of Finance, 43, 1-19. https://doi.org/10.1111/j.1540-6261.1988.tb02585.x

Wang, C. Y. (2005). Ownership and operating performance of Chinese IPOs. Journal of Banking and Finance, 29(7), 1835. https://doi.org/10.1016/j.jbankfin.2004.07.003

Wei, Z. B., \& Varela, O. (2003). State equity ownership and firm market performance: evidence from China's newly privatized firms. Global Finance Journal, 14, 65-82. https://doi.org/10.1016/S1044-0283(03)00005-X

Wei, Z. B., Xie, F. X., \& Zhang, S. R. (2005). Ownership structure and firm value in China's privatized firms: 1991-2001. Journal of Financial and Quantitative Analysis, 40(1), 87. https://doi.org/10.1017/S0022109000001757

Zainudin, N. (2008). Tracking the credit collection period of Malaysian small and medium-sized enterprises. International Business Research, 1(1), 78-86.

Zhu, J. (2000). Multi-factor performance measure model with an application to Fortune 500 
companies, European Journal of Operational Research, 123(1), 105-124. https://doi.org/10.1016/S0377-2217(99)00096-X

\section{Copyright Disclaimer}

Copyright for this article is retained by the author(s), with first publication rights granted to the journal.

This is an open-access article distributed under the terms and conditions of the Creative Commons Attribution license (http://creativecommons.org/licenses/by/3.0/). 